\title{
FROM BARCHAN TO DOMIC SHAPE: EVOLUTION OF A COASTAL SAND DUNE IN NORTHEASTERN BRAZIL BASED ON GPR SURVEY
}

\author{
Josibel G. Oliveira Jr. ${ }^{1,2}$, Walter E. Medeiros ${ }^{1}$, Werner F. Tabosa ${ }^{1}$ and Helenice Vital ${ }^{1}$ \\ Recebido em 16 agosto, 2007 / Aceito em 14 dezembro, 2007 \\ Received on August 16, 2007 / Accepted on December 14, 2007
}

\begin{abstract}
A sand dune located near São Bento do Norte and Caiçara do Norte towns (northern coastal region of Rio Grande do Norte state, Northeastern Brazil) is rapidly migrating toward urban areas. To understand the depositional processes (evolution of the dune), a Ground Penetrating Radar (GPR) survey was carried out. The survey is composed by sixteen profiles in E-W direction, which is parallel to the dominant wind direction, and five profiles in N-S direction. In both directions, it was used antennas of $200 \mathrm{MHz}$ and $80 \mathrm{MHz}$. Additionally, a topographic survey, excavations of two trenches, and grain size analysis were also carried out. The GPR imaged the internal sedimentary structures of the coastal deposits so that it was possible to reconstruct the depositional history of the area. Initially, marine sediments were deposited during the final period of a marine regression of Holocene age. After the exposure of the area, a first phase of aeolian deposition occurred over the marine sediments. Later, a depositional hiatus took place, probably associated with partial erosion of the dune. Finally, a second phase of aeolian deposition occurred, covering all previous strata. Based on the geometry of foresets and bounding surfaces, it was interpreted that, in the second phase of aeolian deposition, the dune changed its morphology from barchan to dome. The morphology change appears to have occurred when the migration front of the dune faced the obstacle constituted by a ramp along in the depositional surface dipping against the wind direction. According to the similarities of the foreset dips in the first and second phases of aeolian deposition, the prevailing dominant winds were very similar to present day dominant winds. So, it is likely that the rapidly migration process of the dune toward urban areas is an entirely natural process.
\end{abstract}

Keywords: dune evolution, GPR, dome-shaped dune, barchan dune, northeast Brazil, coastal deposits.

RESUMO. Uma duna localizada próxima às cidades de São Bento do Norte e Caiçara do Norte (litoral nordeste do Rio Grande do Norte, nordeste brasileiro) está migrando rapidamente sobre áreas urbanas. Para entender o processo deposicional (evolução da duna), um levantamento com Radar Penetrante no Solo (GPR) foi realizado. 0 levantamento é composto por dezesseis perfis na direção E-W, paralelos à direção dos ventos dominantes, e cinco perfis na direção N-S (utilizando antenas de $200 \mathrm{MHz}$ e $80 \mathrm{MHz}$ ). Adicionalmente, foram efetuados escavações de duas trincheiras, um levantamento topográfico e análises granulométricas. 0 GPR imageou as estruturas sedimentares dos depósitos costeiros de modo que foi possível reconstruir a história deposicional da área. Inicialmente, sedimentos marinhos foram depositados durante o período final de uma regressão marinha ocorrida no Holoceno. Após a exposição da área, uma primeira fase de deposição eólica ocorreu sobre os sedimentos marinhos. Mais tarde, ocorreu um hiato deposicional, provavelmente associado com a erosão parcial da duna. Finalmente, ocorreu uma segunda fase de deposição eólica, cobrindo todos os estratos anteriores. Com base na geometria dos foresets e nas superfícies limitantes, foi interpretado que, dentro da segunda fase de deposição eólica, a duna mudou sua morfologia de barcana para dômica. A mudança na morfologia parece ter ocorrido quando a frente de migração da duna encontrou um obstáculo constituído por uma rampa ao longo da superfície deposicional. Devido às semelhanças entre os mergulhos dos foresets dentro da primeira e da segunda fase de deposição eólica, os antigos ventos dominantes foram muito similares aos atuais. Portanto, é provável que o rápido processo de migração da duna em direção a áreas urbanas seja um processo totalmente natural.

Palavras-chave: evolução de duna, GPR, duna dômica, duna barcana, nordeste brasileiro, depósitos costeiros.

\footnotetext{
1 Programa de Pesquisa e Pós-Graduação em Geodinâmica e Geofísica, Departamento de Física/Departamento de Geologia, Centro de Ciências Exatas e da Terra, Universidade Federal do Rio Grande do Norte, 59072-970, Natal, RN, Brazil. Phone/Fax: + 55 (84) 3215-3831 - E-mails: josibel@flamoil.com.br, walter@dfte.ufrn.br, farkatt@yahoo.com, helenice@geologia.ufrn.br

2 Flamoil Serviços Ltda., Rua Seridó, 479, Sala 200, Petrópolis, 59020-010, Natal, RN, Brazil. Phone/Fax: + 55 (84) 3221-4043
} 


\section{INTRODUCTION}

The internal sedimentary structures of consolidated aeolian deposits have long been studied (Brookfield, 1977). However, until the nineties, few studies were available from modern dunes (e.g. McKee, 1966, 1979; Tsoar, 1982; Rubin \& Hunter, 1985) because of the difficulties in sampling or excavating trenches in no consolidated dry sand bodies. The availability of Ground Penetrating Radar (GPR) method, since the nineties, provided a fast noninvasive tool to image in detail near surface sedimentary structures (e.g. Gawthorpe et al., 1993; Schenk et al., 1993; Harari, 1996; Bristow et al., 1996; Silva \& Scherer, 2000; Neal \& Roberts, 2000, 2001; Van Dam, 2002; Oliveira Jr. et al., 2003; Pedersen \& Clemmensen, 2005). Comprehensive reviews of the use of GPR in sedimentological studies were done by Neal (2001) and Bristow \& Jol (2003).

In this study, the depositional history of a recent dome-shaped sand dune is reconstructed based on GPR data interpretation. The studied dune is located near São Bento do Norte and Caiçara do Norte towns, in the northern coastline of Rio Grande do Norte State, Northeastern Brazil (Fig. 1). A comprehensive resume of the Holocene stratigraphy of the area was recently done by Caldas et al. (2006). Because the studied dune is rapidly migrating towards urban areas of Caiçara do Norte town (Fig. 2), a better understanding of its evolution is necessary or important (Tabosa, 2000, 2002; Hustedt, 2000; Oliveira Jr., 2001; Tabosa et al., 2001) in order to guide preventive actions. A GPR survey was done in order to obtain information about the depositional history of the dune and, in particular, to verify if significant changes in the wind direction occurred. Preliminary results of this study were presented by Oliveira Jr. et al. (2003). Data interpretation indicated that the dune probably changed its morphology from a barchan to a dome shape, in very good accordance with changes in the depositional process as described by McKee (1966). This aim of this paper is dedicated to this issue.

\section{STUDY AREA}

The coastal region of São Bento do Norte (Figs. 1 and 2) is a plain showing maximum gradient around $5^{\circ}$, except where dunes occur (Vilaça et al., 1991). Several morphological elements are present, such as sand dunes, sand banks, shell middens, tidal flats, beaches, and beach rocks (Caldas, 1996; Tabosa, 2000; Tabosa et al., 2001).

The climate is semi-arid (mean annual rainfall around $800 \mathrm{~mm}$ ) with annual mean temperature equal to $26.5^{\circ} \mathrm{C}$ and maximum variation of about $5^{\circ} \mathrm{C}$. Air humidity is normally equal or greater than $68 \%$ (IDEMA, 1999). The wind blows up from East in the period August-April and from Northeast in the period May-July. From March to June, the mean wind velocity is equal to $4.8 \mathrm{~m} / \mathrm{s}$ while between August and December the winds are stronger with mean velocity around $9.0 \mathrm{~m} / \mathrm{s}$ (Costa Neto, 1997; Tabosa, 2002). A frequency distribution plot of the wind directions is shown in Figure 3.

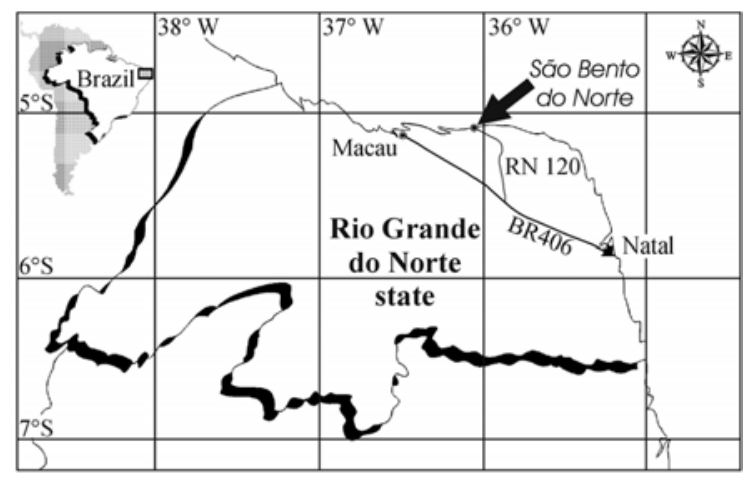

Figure 1 - Location of the studied area in Rio Grande do Norte State, Northeastern Brazil. RN120 and BR406 are the main roads in the area.

Sand supply to some portions of the coastline is the result of longshore currents. Because the wind direction is approximately constant (E-NE), long sandy sheets are along the coast. Dune sands are formed by fine to medium grain sizes with moderate sorting and composed mainly by quartz and shell fragments.

\section{METHODOLOGY}

GPR is a tool (of exploration) which images the shallow subsurface of the Earth (usually up to $30 \mathrm{~m}$ ) using electromagnetic waves with frequency in the range $10 \mathrm{MHz}-1000 \mathrm{MHz}$. Because electromagnetic waves share relevant cinematic similarities with elastic waves, GPR data interpretation and processing can be conducted in a manner similar to other seismic data as long as caution is taken in order to correct dispersion effects (Xavier Neto \& Medeiros, 2006).

Dielectric permittivity and conductivity are the relevant physical properties to GPR. Assuming that Earth's subsurface can be modeled as a low loss dielectric medium (Hayt Jr., 1988), dielectric permittivity contrasts are mainly responsible for reflections of GPR signal. Particularly, in sand bodies, dielectric permittivity is controlled mainly by water content, grain size and porosity, and to a minor extent, to magnetic permeability (Topp et al., 1980; Roth et al., 1990; Sutinen, 1992; Huggenberger, 1993; Neal, 2001). On the other hand, conductivity is mainly responsible for GPR signal attenuation; as consequence, the quality of the GPR images depends strongly on the medium conductivity. Because 


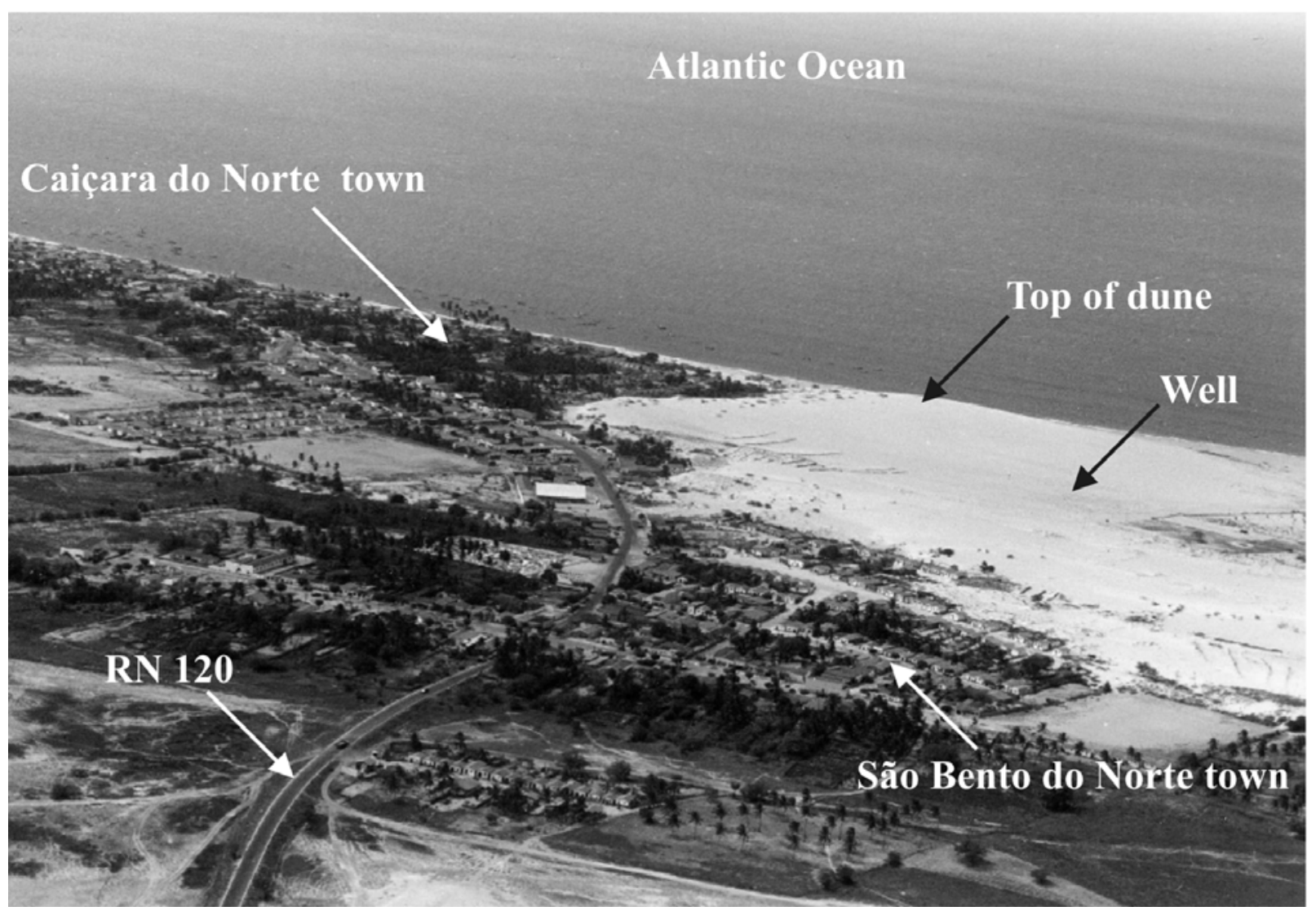

Figure 2 - Oblique photograph of the studied dune taken from a flight in low altitude showing the dune, its top and the well location shown in Figure 4 (Photo: H. Vital, October 2002).

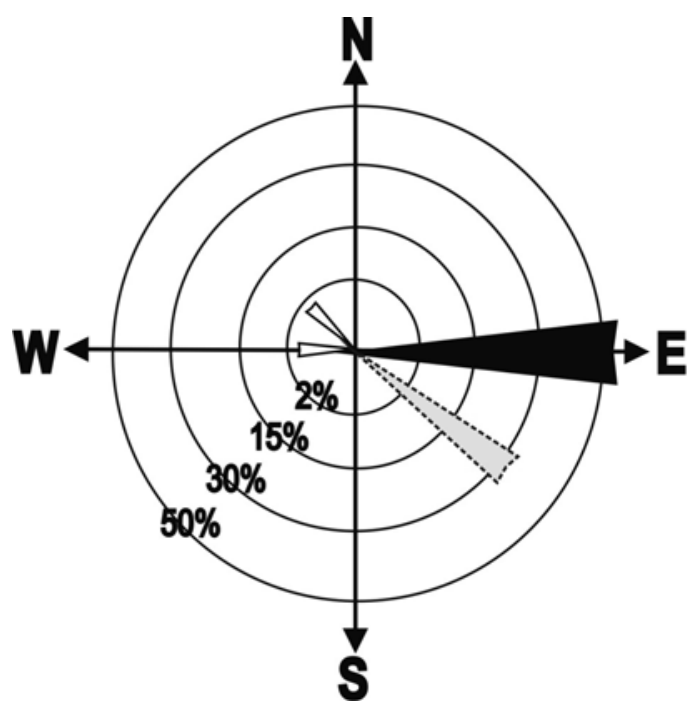

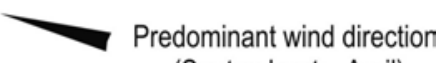

(September to April)

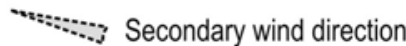

(May to August)

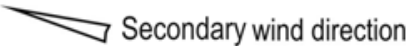

(Minor frequent)

Figure 3 - Frequency distribution plot of the wind direction near Caiçara do Norte town (Tabosa, 2002). 
dunes are in general formed by very low conductive material, as quartz-sand and shell fragments, they offer excellent conditions for GPR imaging, except if they are saturated with salty water. Details about the GPR method may be obtained in Davis \& Annan (1989), for example.

\section{GPR and topographic surveys}

GPR data were obtained along 21 profiles (Fig. 4) using a GSSISIR System 2 equipment. Using a $200 \mathrm{MHz}$ monostatic antenna, 16 profiles along E-W direction - parallel to the dominant wind direction - and 5 profiles along S-N direction were carried out. Profiles L (E-W direction) and T4 (S-N direction) were also surveyed with a bistatic $80 \mathrm{MHz}$ antenna (Fig. 4). For both frequencies, a continuous mode acquisition was used. The distances were measured using an odometer and each trace was collected at steps of $5 \mathrm{~cm}$. Topography was also measured at a maximum of $10 \mathrm{~m}$ spacing along the same profiles using a theodolite. Interpolated elevation contours above sea level are also shown in Figure 4.

\section{GPR data processing}

Using the software REFLEXW (Sandmeier, 2000), the following GPR data processing flux composed by seven steps (Xavier Neto et al., 2001) was applied to the raw data. The $1^{\text {st }}$ step is the zero offset correction. This step corrects the effect in propagation times caused by non-null separation between transmission and reception antennas, thus correctly positioning the Earth's surface in the radargrams. The $2^{\text {nd }}$ step is the removal of inductive effects (WOW). WOW's are effects characterized by low frequency and high amplitude caused by inductive coupling between transmission and reception antennas. Usually, they appear in the early parts of the trace (Young et al., 1995). Because they mask shallow reflectors, they should be removed (Johansson \& Mast, 1994). The $3^{\text {rd }}$ step is background removal where reverberations associated with direct ground and air waves were eliminated. Reverberations appear in radargrams as flat repetitive reflectors, regularly distributed in time. They might be removed by subtracting an averaged trace which is build up from a given time/distance range of the actual section (Sandmeier, 2000). The $4^{\text {th }}$ step is amplitude recovering where spherical and exponential time gains (Sandmeier, 2000) were applied to the traces to correct effects caused by energy absorption and geometrical spreading, although preserving amplitude ratios in the traces. The $5^{\text {th }}$ step is F-K Migration (Stolt, 1978) where lateral events were correctly positioned in time. In particular, diffractions patterns were concentrated in their original points. The migration velocity $(0.13 \mathrm{~m} / \mathrm{ns})$ was previously estimated by fitting hyperbolas associated to diffraction patterns in non-migrated radargrams (Olhoeft, 2000). F-K migration is a very good migration tool if the medium is approximately homogeneous (Stolte, 1994), which is the case of sand dunes. The same velocity $(0.13 \mathrm{~m} / \mathrm{ns})$ was also used for time-depth conversion. The $6^{\text {th }}$ step is a low-pass filtering and Automatic Gain Control (AGC) where spurious high frequency events were eliminated with low-pass filtering using cutting frequencies around $250 \mathrm{MHz}$ and $550 \mathrm{MHz}$ for data measured with $80 \mathrm{MHz}$ and $200 \mathrm{MHz}$, respectively. In this step amplitudes were equalized with $A G C$ gain. $A G C$ changes amplitude ratios in the traces but emphasizes continuity in geometrical features in radargrams, thus making easier to interpret internal sedimentary boundaries, as in the present study. Finally, the $7^{\text {th }}$ step consists of topographic correction where effects due to the fact that the Earth's surface is not flat are corrected in the radargrams. In this step, the standard approach described by Sandmeier (2000) was used. Examples of radargrams resulting from this processing flux are shown in Figures 5a to 9a.

\section{RESULTS AND DISCUSSION \\ GPR data interpretation}

The resolution in the radargrams was sufficient to view in detail the internal sedimentary structures, (Figs. 5a, 5b and 6a): single foreset (as Mark 1, for example); the contact between two different dune generations, that is, a second order bounding surface (Mark 2); third order bounding surfaces (Mark 3); layers of sediments identified by Caldas et al. (2006) as beach ridges associated to marine deposits (Mark 4); contact between marine sediments on bottom and aeolian sediments on top (Mark 5). The water table was also detected (Mark 6) and its depth was checked by measuring the depth to the free water surface in the open well shown in Figures 2 and 4 . The fact that Marks 5 and 6 appear as expected as very continuous and horizontal surfaces reveals that the processing flux, in particular the migration and topographic correction steps, does not alter significantly the structures dips.

\section{Stratigraphic units}

All sediments deposited above the surface indicated by Mark 5 (Fig. 5b) present undoubtedly aeolian origin because they outcrop and the sedimentation process is still occurring today. On the other hand, sediments deposited below surface indicated by Mark 5 (Fig. 5b) are marine sediments according to Caldas et al. (2006). These sediments were deposited in the final 

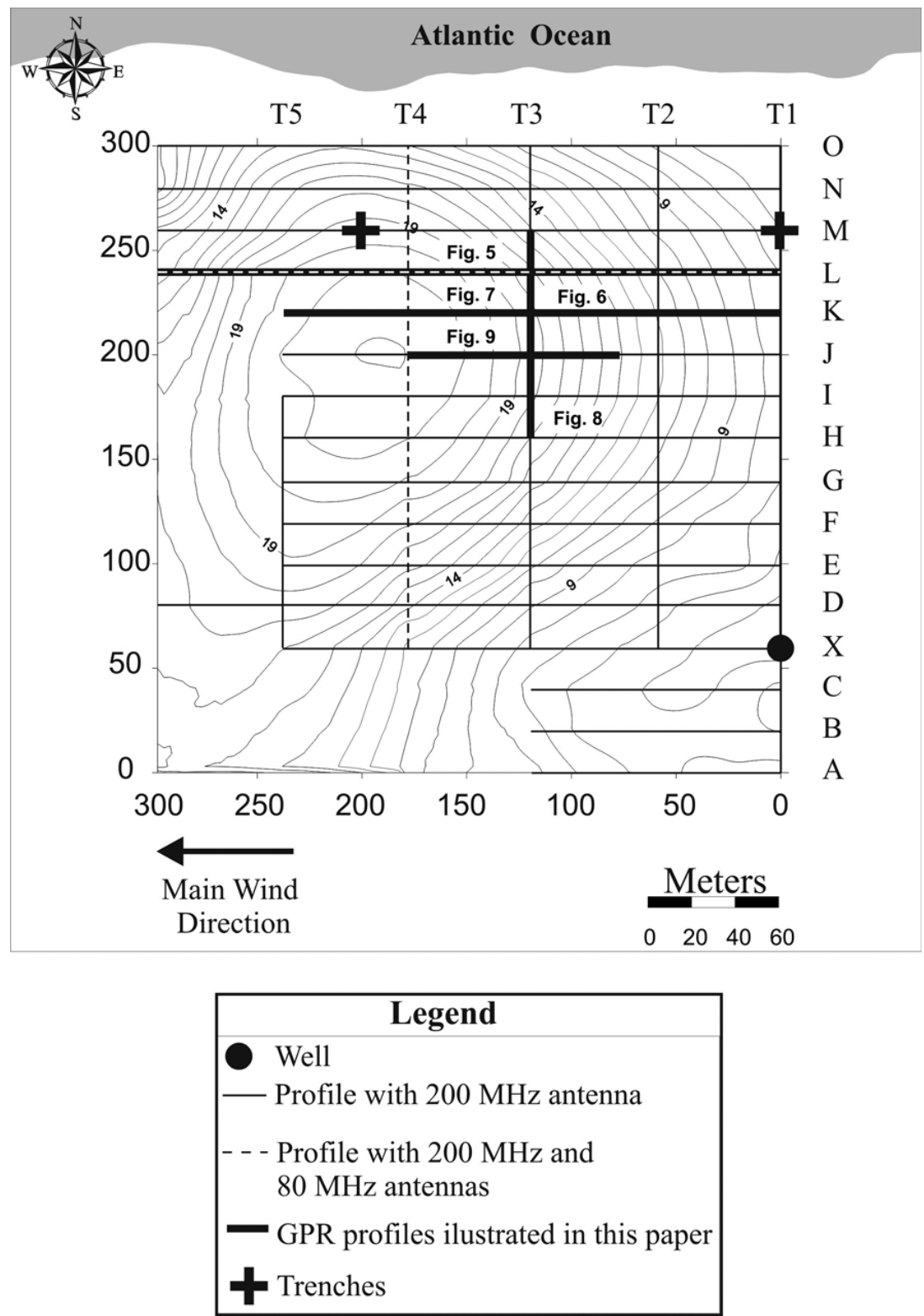

Figure 4 - Topographic map of the studied dune. Contours are given in meters. The lines along which GPR and topographic profiles were measured and trenches were excavated are also indicated.

period of the last Holocene regression in the area. The conclusions from Caldas et al. (2006) were based on vibracore descriptions and radiocarbon dating, besides GPR imaging. To corroborate the results of Caldas et al. (2006), observe that inside these marine sediments, internal structures, indicated by Mark 4, appear as subhorizontal layers in all E-W radargrams (e.g. Figs. 5, 6 and 7), which are parallel to the coastline. On the other hand, the same structures appear dipping toward the sea in radargrams orthogonal to the coastline (e.g. Fig. 8).
Because we are very confident about the origin of the sediments, it is possible to separate precisely all stratigraphic units from the radargrams, as shown in Figure 10. Aeolian unit S2 is divided in two sub-units S2a and S2b because a very clear third order bounding surface (Mark 3 in Figs. 5b and $6 \mathrm{~b}$ ) can be identified in the radargrams (Figs. 5a and 6a). In addition, within sub-units S2a and S2b, the foresets dips vary rather smoothly thus corroborating the interpretation of two phases of sedimentation associated to S2. On the other hand, aeolian unit S1 is not 
(a) E Distance (m) W

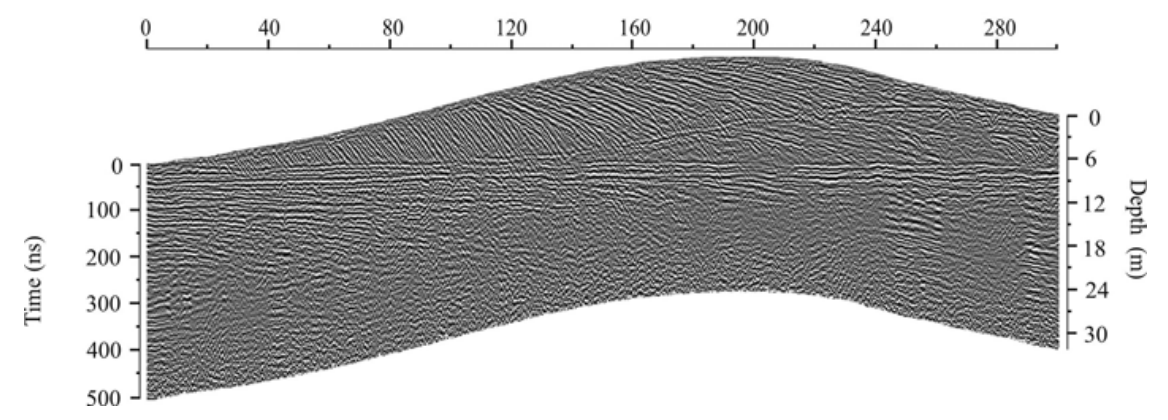

(b)

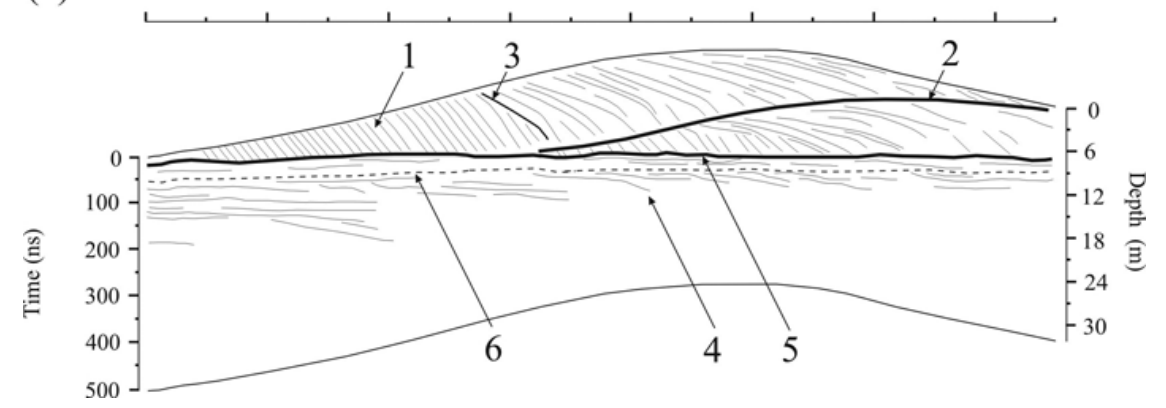

Figure 5 (a) - Processed GPR profile L, measured in E-W direction. Frequency center equals to $80 \mathrm{MHz}$. (b) - GPR profile L, measured in E-W direction. Interpretation: Mark 1 - individual foreset. Mark 2 - interface separating different dune generations or second order bounding surface. Mark 3 - third order bounding surface. Mark 4 - sand ridges associated to marine deposition. Mark 5 - interface separating marine sediments on bottom, and aeolian sediments on top. Mark 6-water table.

divided because its deposition history appears to be of more complex nature: judging by the variation of the foresets dips inside S1, several third-order bounding surfaces can be identified as Marks 3a, 3b, and 3c (Fig. 7b).

In addition it is possible to verify the dependence of the foreset dips with the dominant wind directions inside aeolian units S1 and S2. Regarding to S2 unit, note that the crossing point between profiles K (E-W direction) and T3 (S-N direction) are indicated both in Figures $7 \mathrm{~b}$ and $8 \mathrm{~b}$. The same structure (Mark 1a), below this crossing point, shows angles around $9^{\circ}$ in $\mathrm{E}-\mathrm{W}$ direction (Fig. 7) and $0^{\circ}$ in S-N direction (Fig. 8), thus confirming that the maximum dip of the foreset occurs in the direction parallel to the dominant wind direction.

Regarding to $S 1$ unit, the crossing point between profiles $J$ (E-W direction) and T3 (S-N direction) is shown both in Figures $8 \mathrm{~b}$ and $9 \mathrm{~b}$. The same foreset (Mark 1c), below this crossing point, shows angles around $10^{\circ}$ in E-W direction (Fig. 9) and $0^{\circ}$ in S-N direction (Fig. 8). Therefore, judging by the similarities of the foresets dips inside $\mathbf{S 1}$ and $\mathbf{S}$, the prevailing past wind was probably very similar to the nowadays dominant wind.

\section{Morphology change of the dune}

According to McKee (1966), dome-shaped dunes lack a welldeveloped down-wind steep slip face. The most characteristic internal structure of dome-shaped dunes is the fact that foreset lamina present low angles, even in the downwind part of the dune. In general, near the summit point, foresets are subhorizontal. The dominant depositional processes in dome-shaped dunes are tractional and grainfall depositions.

On the other hand, barchan dunes are crescent-shaped sand mounds which occur mostly as isolated sand bodies. A barchan dune migrates by successive avalanches of sand on the slip face, so the dominant depositional process is grainflow and, to a minor extent, grainfall. In general, the foresets dip around $26^{\circ}$ to $34^{\circ}$ along the wind direction. The horn tips of a barchan dune extend forward in the downwind direction because they migrate more rapidly than the main body (McKee, 1966). In general, barchan dunes are formed by unidirectional winds, under low sand supply conditions, and seem to occur in flat areas with thin or poor sand cover. The presence of a topographic obstacle in the 
(a)

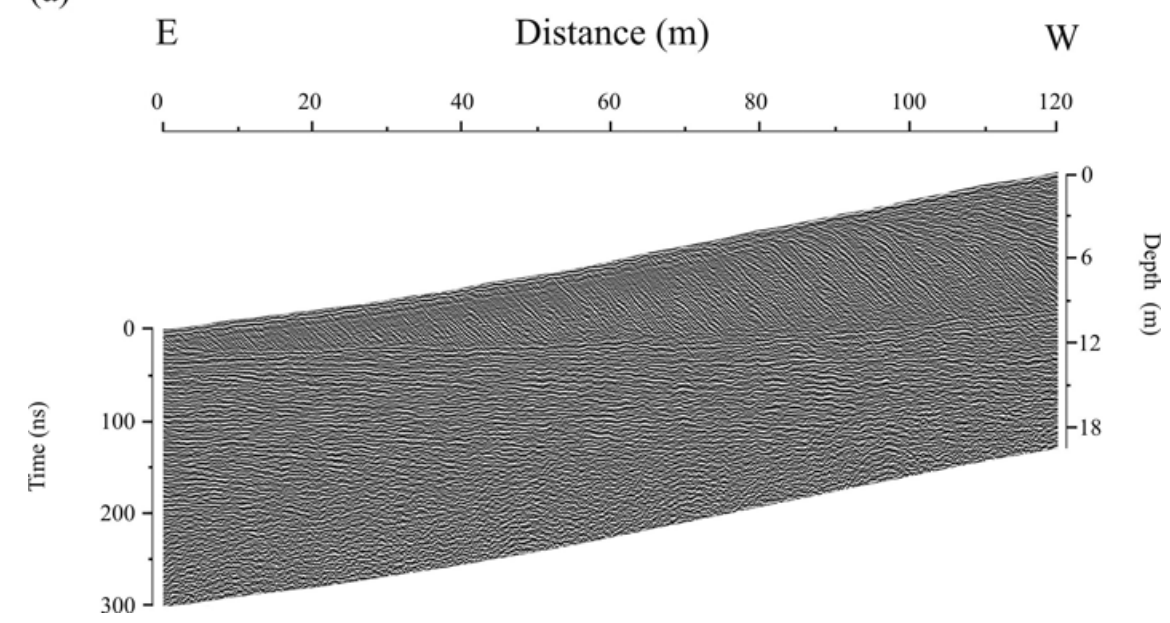

Line

T3

(b)

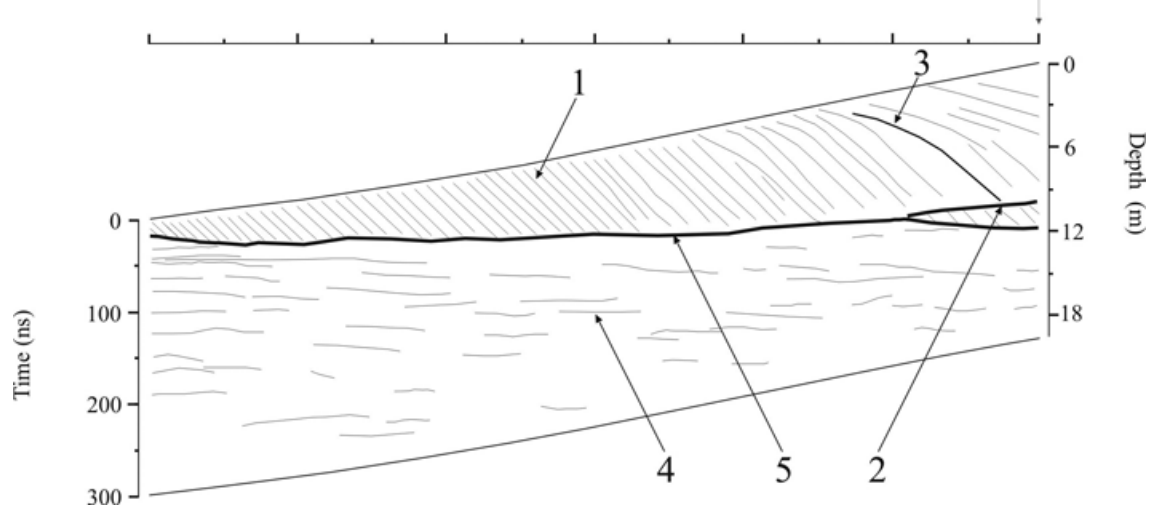

Figure 6 (a) - Processed segment of GPR profile K (0 m-120 m), measured in E-W direction. Frequency center equals to $200 \mathrm{MHz}$. (b) - Segment of GPR profile K (0 m-20 m), measured in E-W direction. Interpretation: Marks 1 to 5 are described in the caption of Figure 5b. The crossing point with GPR profile T3 (Fig. 8) is indicated. A change in the dune morphology from barchan to dome-shaped is associated to the interpreted third order bounding surface indicated by Mark 3.

depositional surface may cause a change in the morphology of a dune (Harari, 1996).

Nowadays the morphology of the studied dune is domeshaped (Fig. 4). However, strong variation occur in the foreset dips along the wind direction inside stratigraphic unit S2: while in Figure 6 (Mark 1) the foreset dip is around $27^{\circ}$, in Figure 7 the foreset dips present both intermediate values ( $9^{\circ}$ in Mark 1a) and low values ( $2^{\circ}$ in Mark 1b). Only the foreset dips present around the top of the dune are in accordance with its current dome shape. Figure 11 shows a 3D view of what would be the elevation of the dune if the sandy volume associated to the stratigraphic sub-unit S2b (Fig. 10) were removed. Observe that the shape of the southern ridge associated to the bounding surface indica- ted by Mark 3 resembles a horn (Fig. 11). Because the northern ridge associated to the bounding surface indicated by Mark 3 is too close to the sea it might be very affected by erosion. By this reason, we did not use it in the interpretation.

Two trenches were excavated (line M, Fig. 4) and grain size analyses were done with the collected sand samples. The first trench was excavated in the bottomset of the dune, in position $0 \mathrm{~m}$, and the second trench was excavated near the topset of the dune, in position $200 \mathrm{~m}$ (Fig. 4). In the first trench (Fig. 12), parallel lamina was observed with thicknesses varying from 3 to $6 \mathrm{~cm}$, dipping between $25^{\circ}$ and $30^{\circ}$; sand forming these lamina present unimodal sorting. In the second trench (Fig. 13), subhorizontal parallel lamina was observed with thicknesses up to $5 \mathrm{~mm}$ and 
(a)
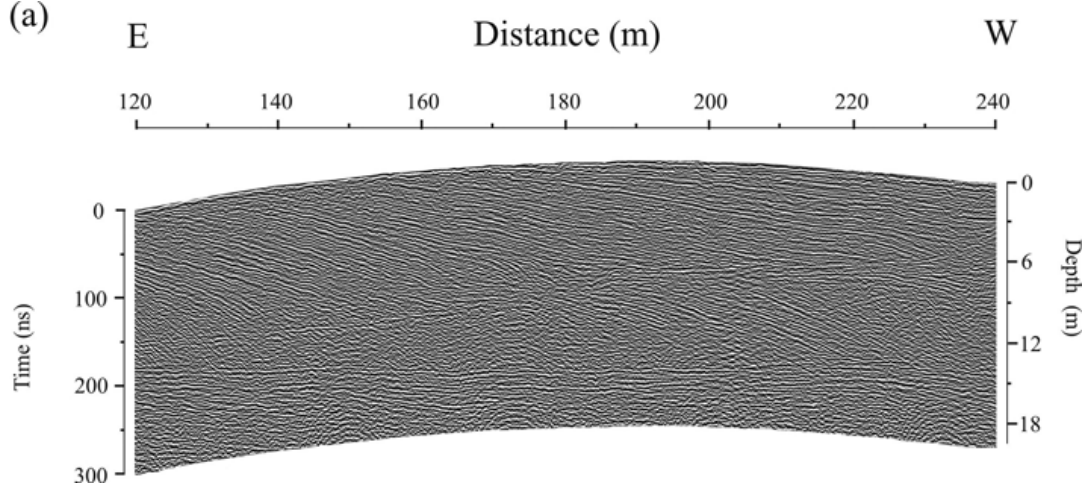

(b) Line

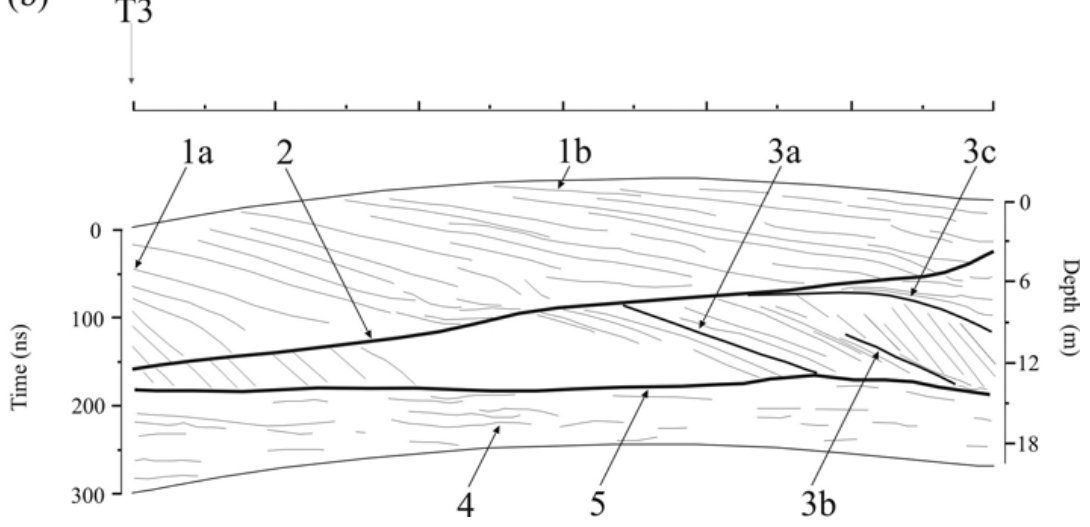

Figure 7 (a) - Processed segment of GPR profile K (120 m-240 m), measured in E-W direction. Frequency center equals to $200 \mathrm{MHz}$. (b) - Segment of GPR profile K (120 m-240 m), measured in E-W direction. Interpretation: Marks 1a and $1 \mathrm{~b}$ - individual foresets. Mark 2 - interface separating different dune generations or second order bounding surface. Marks 3a, 3b, and $3 c$ - third order bounding surface. Mark 4 - sand ridges associated to marine deposition. Mark 5 - interface separating marine sediments on bottom and aeolian sediments on top. The crossing point with GPR profile T3 (Fig. 8) is indicated. Below this crossing point, the same foreset (Mark 1a), inside the second phase of aeolian deposition, shows angles around $9^{\circ}$ along $\mathrm{E}-\mathrm{W}$ direction (this figure) and $0^{\circ}$ along S-N direction (Fig. 8), as consequence of the E-W dominant wind direction.

sand is bimodal sorting. According to Mountney \& Howell (2000), strata showing these characteristics may be the result of grainflow and tractional depositional processes, respectively, in accordance to the dominant processes described by McKee (1966) for barchan and dome-shaped dunes. Let us stress that foresets dips measured in the trenches are in a very good accordance with dips shown by radargrams (Figs. 5 to 7 ).

Interpretation of the data allows to discuss the shape of the dune during its evolution: the portion of the dune showing high foreset dips, associated to stratigraphic sub-unit S2a, was interpreted as a remain of an older barchan dune. In other words, it is evidence that the present dome-shaped dune was previously a barchan.

The abrupt change of the foreset dips inside the strati- graphic unit S2 is separated by the bounding surface indicated by Mark 3, which is the interface separating sub-units S2a and S2b (Figs. 5 and 10). In profiles $L$ and $K$, these abrupt changes occur around position $120 \mathrm{~m}$, as shown both in Figure 5 $(80 \mathrm{MHz})$ and $6(200 \mathrm{MHz})$. This position lies approximately above the eastern end point (or border, in 3D) of the bounding surface indicated by Mark 2, where this surface touches the surface indicated by Mark 5. Observe that the surface indicated by Mark 5 is flat; on the other hand the surface indicated by Mark 2 constitutes a ramp inclined against the wind direction in its eastern portion (Fig. 4b). The interpretation proposed here is that when the migration front of the dune faced the obstacle constituted by this ramp (Harari, 1996), the depositional processes gradually changed from grainflow (and grainfall) to tractional depo- 

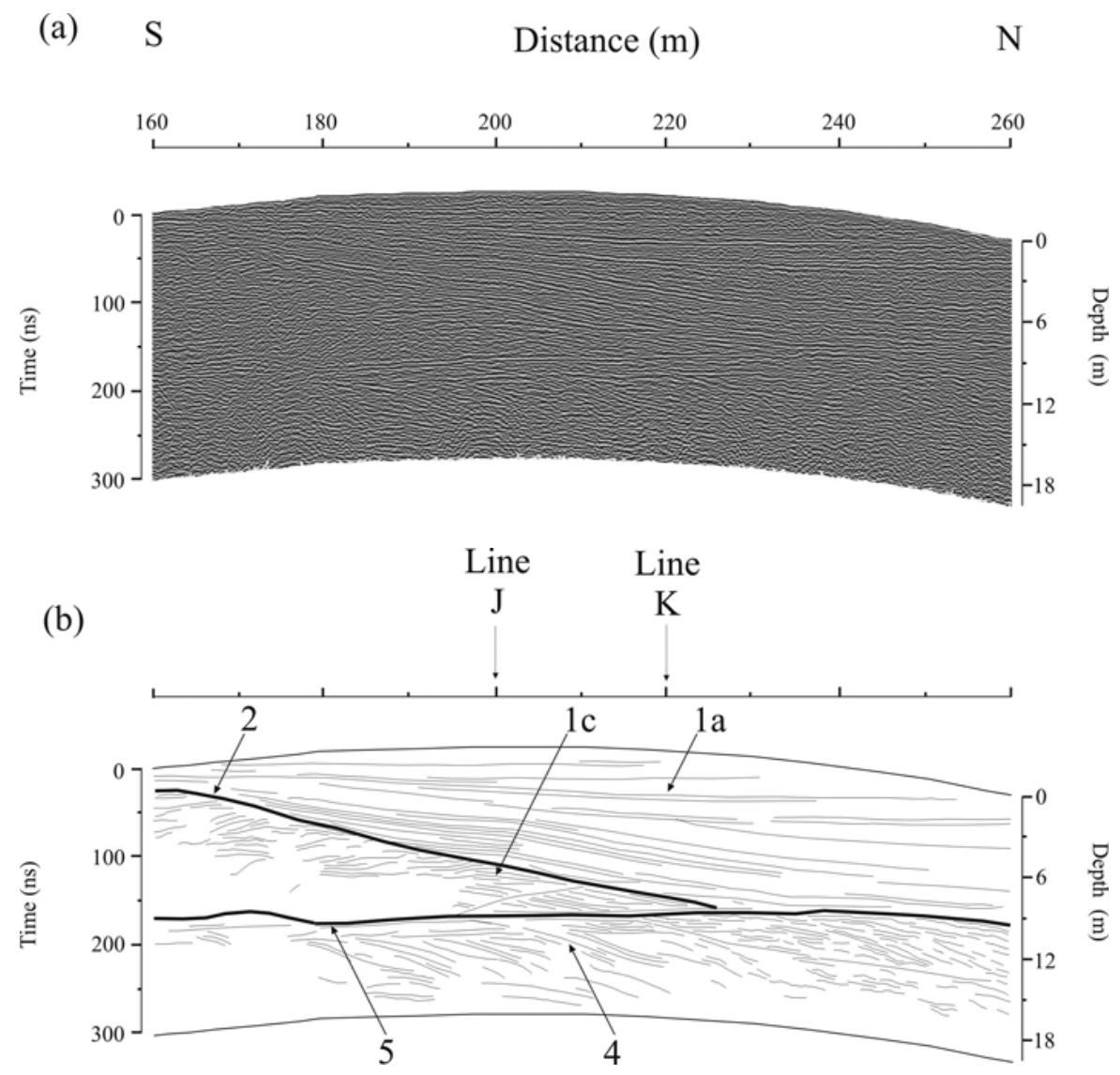

Figure 8 (a) - Processed segment of GPR profile T3 (160 m-260 m), measured in S-N direction. Frequency center equals to $200 \mathrm{MHz}$. (b) - Segment of GPR profile T3 (160 m-260 m), measured in S-N direction. Interpretation: Marks 1a and $1 \mathrm{C}-$ individual foresets. Mark 2 - interface separating different dune generations or second order bounding surface. Mark 4 - sand ridges associated to marine deposition. Mark 5 - interface separating marine sediments on bottom and aeolian sediments on top. The crossings points with GPR profiles $\mathrm{J}$ and $\mathrm{K}$ are indicated. Mark $1 \mathrm{c}$ (in this figure and in Fig. 9b) indicates foresets, inside the first phase of aeolian deposition, showing a similar dependence of the dips with wind direction as the dependence described for the foresets inside the second phase of aeolian deposition in Figure 7.

sition. This change in the depositional process ultimately caused the change of the dune morphology from barchan to domeshaped. In this way, the surface indicated by Mark 3 is the associated third-order surface (Brookfield, 1977).

\section{Depositional history of the area}

Four stages for conduction of the depositional processes in the area are recognized (Figs. 14a to 14d): Stage 1 corresponds to deposition of marine sediments (stratigraphic unit S0 in Fig. 10) during the final period of the last Holocene marine regression (Fig. 14a) (Caldas, 2002; Caldas et al., 2006). After the exposure of the area (stage 2 in Fig. 14b) aeolian deposition took place (stratigraphic unit S1 in Fig. 10) over the marine sediments. Later, a depositional hiatus happened, probably affected by erosion on parts of the dune and, finally, a second phase (stages 3 and 4 in Figs. 14c and 14d, respectively) of aeolian deposition occurred (stratigraphic sub-units S2a and S2b in Fig. 10), covering all previous strata.

Based on the geometry of the foresets and bounding surfaces, it was interpreted that, in the second phase of aeolian deposition, the morphology of the dune changed from barchan (stage 3 in Fig. 14c) to dome shape (stage 4 in Fig. 14d) which is the presentday shape. This morphology change appears to have occurred when the migration front of the dune faced the obstacle constituted by a ramp along the depositional surface dipping against the wind direction. In this situation, the depositional process changed gradually from grainflow (and, to a minor extent, grainfall) to tractional deposition and grainfall. 

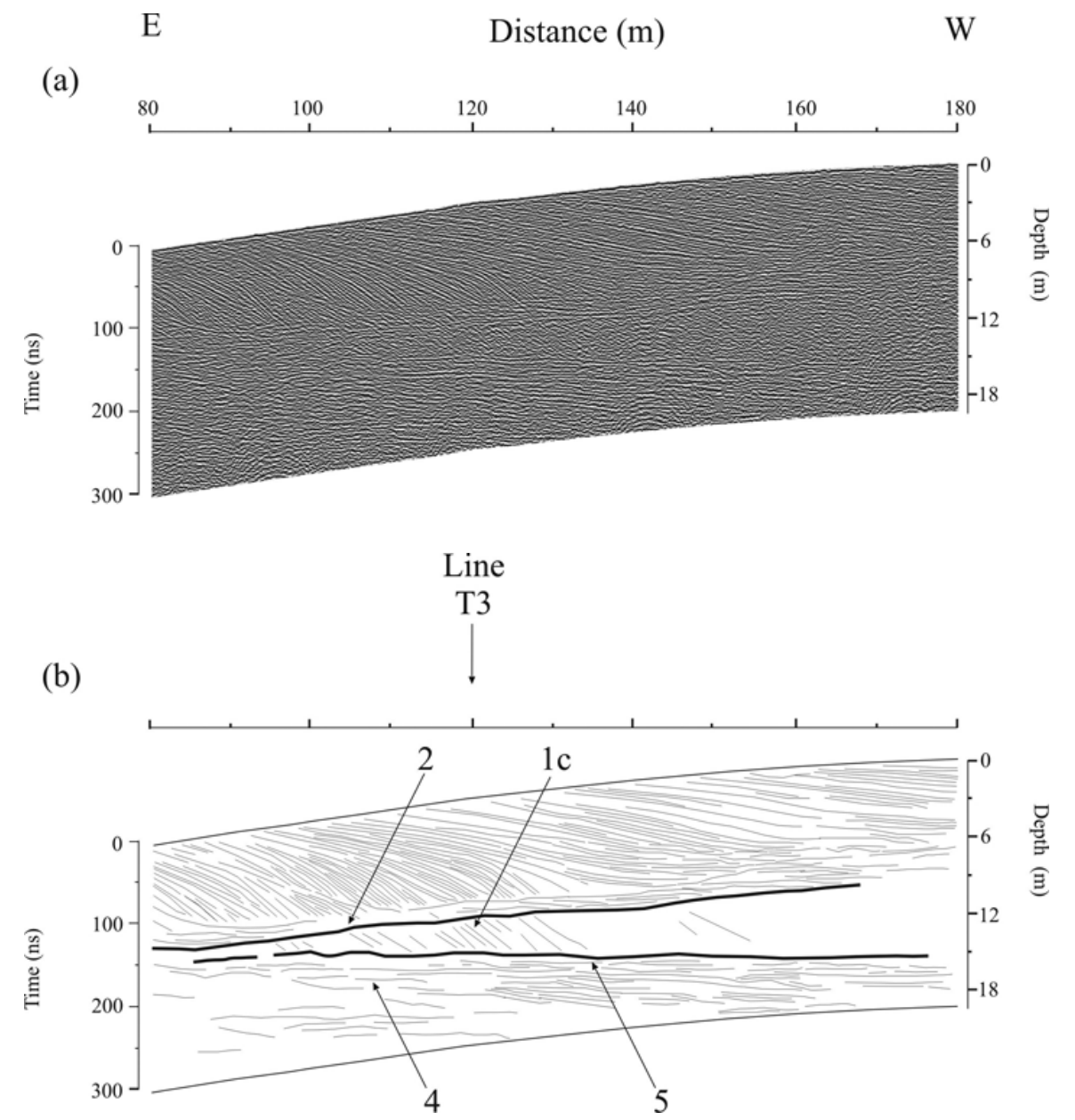

Figure 9 (a) - Processed segment of GPR profile J ( $80 \mathrm{~m}-180 \mathrm{~m})$, measured in E-W direction. Frequency center equals to $200 \mathrm{MHz}$. (b) - Segment of GPR profile J $(80 \mathrm{~m}-180 \mathrm{~m})$, measured in E-W direction. Interpretation: Mark 1c individual foreset. Mark 2 - interface separating different dune generations or second order bounding surface. Mark 4 - sand ridges associated to marine deposition. Mark 5 - interface separating marine sediments on bottom and aeolian sediments on top. The crossings points with GPR profile T3 is indicated. Mark $1 \mathrm{c}$ (in this figure and in Fig. 8b) indicates foresets, inside the first phase of aeolian deposition, showing a similar dependence of the dips with wind direction as the dependence described for the foresets inside the second phase of aeolian deposition in Figure 7.

\section{CONCLUSIONS}

The GPR survey imaged the internal sedimentary structures of the coastal deposits so that it was possible to reconstruct the depositional history of the area, because the resolution in the radargrams was sufficient to view in detail the internal sedimentary structures. The fundamental objective of the radar data processing was to enhance the geometry of the internal structures of the due; this justify the application of a AGC gain filter. The studied dune is located near São Bento do Norte and Caiçara do Norte towns, in the northern coastline of Rio Grande do Norte State, Northeastern Brazil.

Based on the relationship among the internal structures of the dune, particularly the differences in geometry of the structures as seen in GPR profiles surveyed along directions parallel and perpendicular to the dominant wind, it was possible to reconstruct the evolution of the dune.

Initially, marine sediments were deposited during the final period of the last Holocene marine regression. Inside these marine sediments, internal structures appear as subhorizontal layers in all radargrams parallel to the coastline. On the other hand, the same structures appear dipping toward the sea in radargrams orthogonal to the coastline, thus corroborating the results of Caldas et al. (2006) about its marine origin.

Then, after the area was exposed, a first phase of aeolian de- 


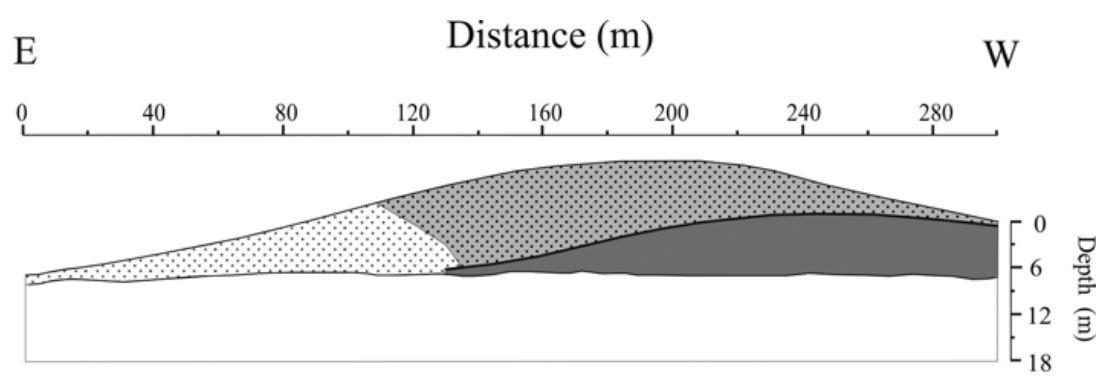

\section{Stratigraphic unit S2 \\ Sub-unit S2b \\ Sub-unit S2a}

\section{Stratigraphic unit S1}

\section{Stratigraphic unit S0}

Figure 10 - Stratigraphic units: S0 - marine sediments. S1 and S2 - aeolian sediments. S2 was divided in two sub-units S2a and S2b. This figure may be compared with Figure 5.

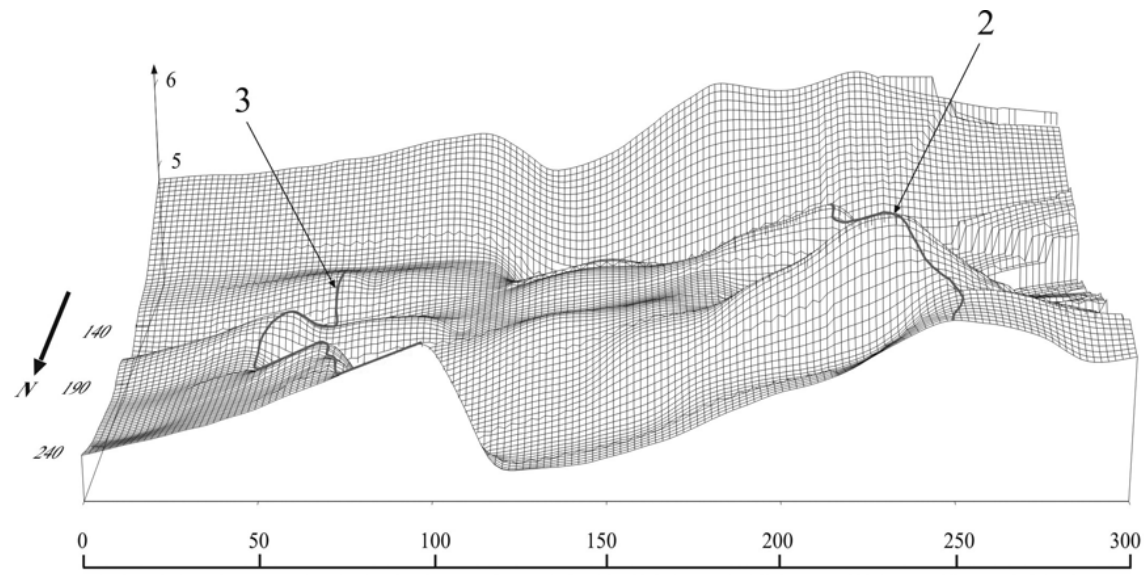

\section{Distance (m)}

Figure 11 - 3D view of what would be the elevation of the dune if the sandy volume associated to the stratigraphic sub-unit S2b (Fig. 10) were removed. Curves indicated by the numbers 2 and 3 correspond to the ridges of the bounding surfaces indicated by Marks 2 and 3 in Figure 5b, respectively. This view was constructed using all surveyed radargrams. All dimensions are given in meters and the reference system is the same used in Figure 4. The front view of this figure corresponds to section along GPR profile L (Fig. 5); thus just the southern ridge of surface indicated by Mark 3 can be seen.

position occurred, directly over marine sediments, followed by a depositional hiatus, when erosion may have occurred in parts of the existing dune. Finally, a second phase of aeolian deposition occurred, covering all previous strata.

It is interpreted that in the second phase of aeolian deposition the dune changed its morphology from barchan to dome-shaped.
This morphology change appears to have occurred when the migration front of the dune faced the obstacle constituted by a ramp, along the depositional surface, dipping against the wind direction. In this situation, the depositional processes changed gradually from grainflow (and, to a minor extent, grainfall) to tractional deposition. 


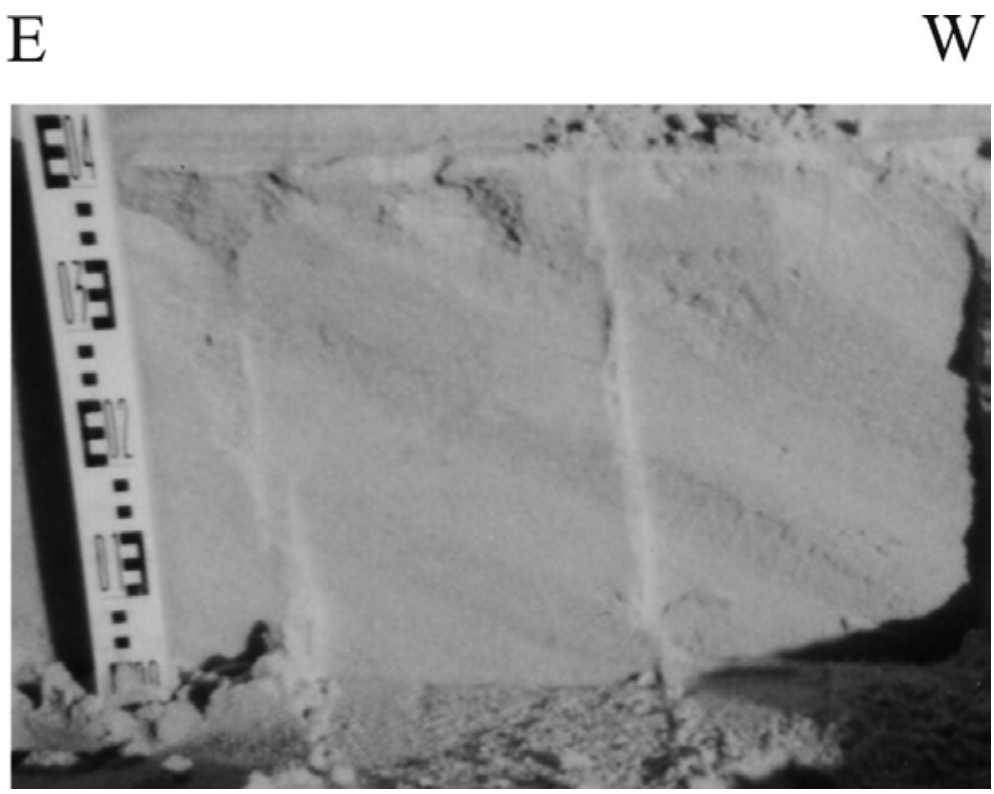

Figure 12 - Photograph of the trench excavated in the bottomset of the dune in position $0 \mathrm{~m}$ (Fig. 4). Parallel laminae with thicknesses varying from 3 to $6 \mathrm{~cm}$ and dips between $25^{\circ}$ and $30^{\circ}$ can be seen. These laminae were associated to grainflow depositional process in a previous barchan stage of the present dome-shaped dune.

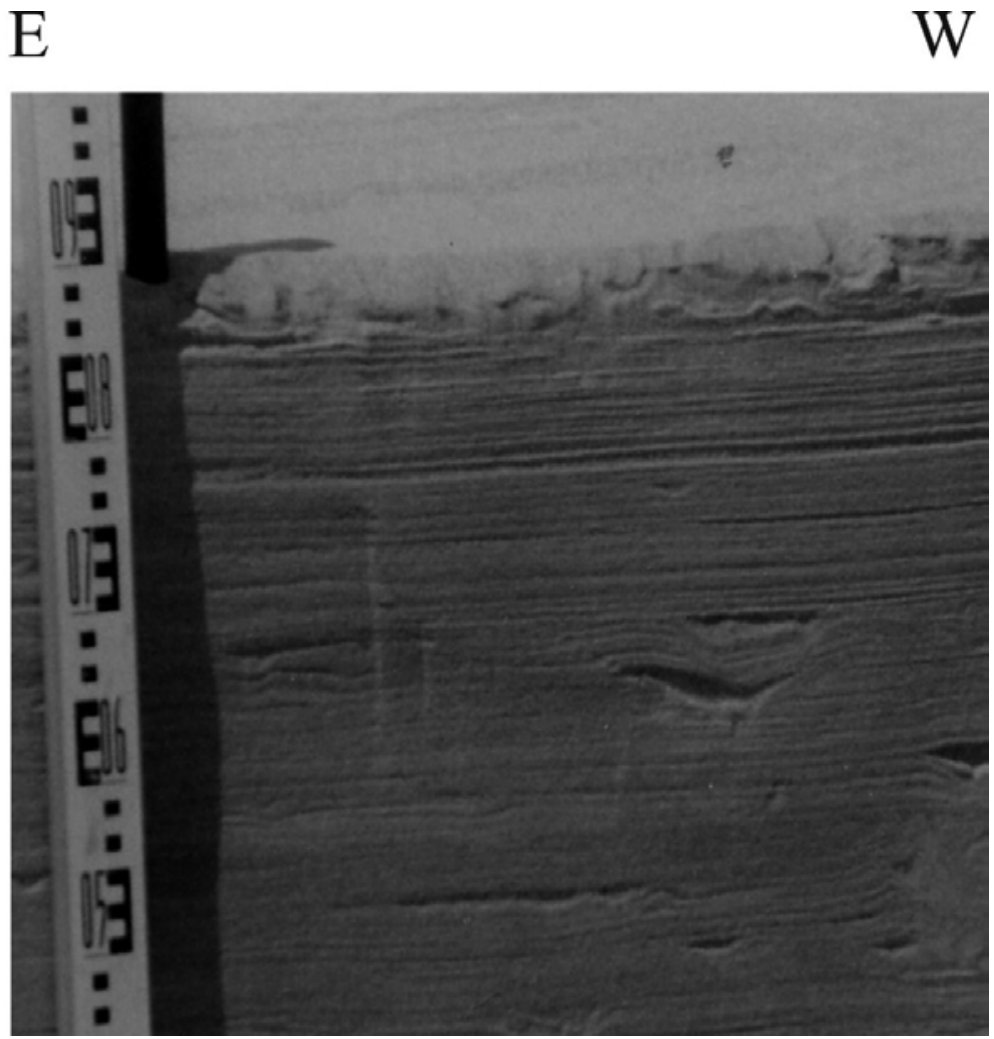

Figure 13 - Photograph of the trench excavated in the topset of the dune in position $200 \mathrm{~m}$ (Fig. 4). Subhorizontal parallel laminae with thicknesses up to $5 \mathrm{~mm}$ can be seen. These laminae were associated to tractional depositional process in the present dome-shaped stage of the dune. 


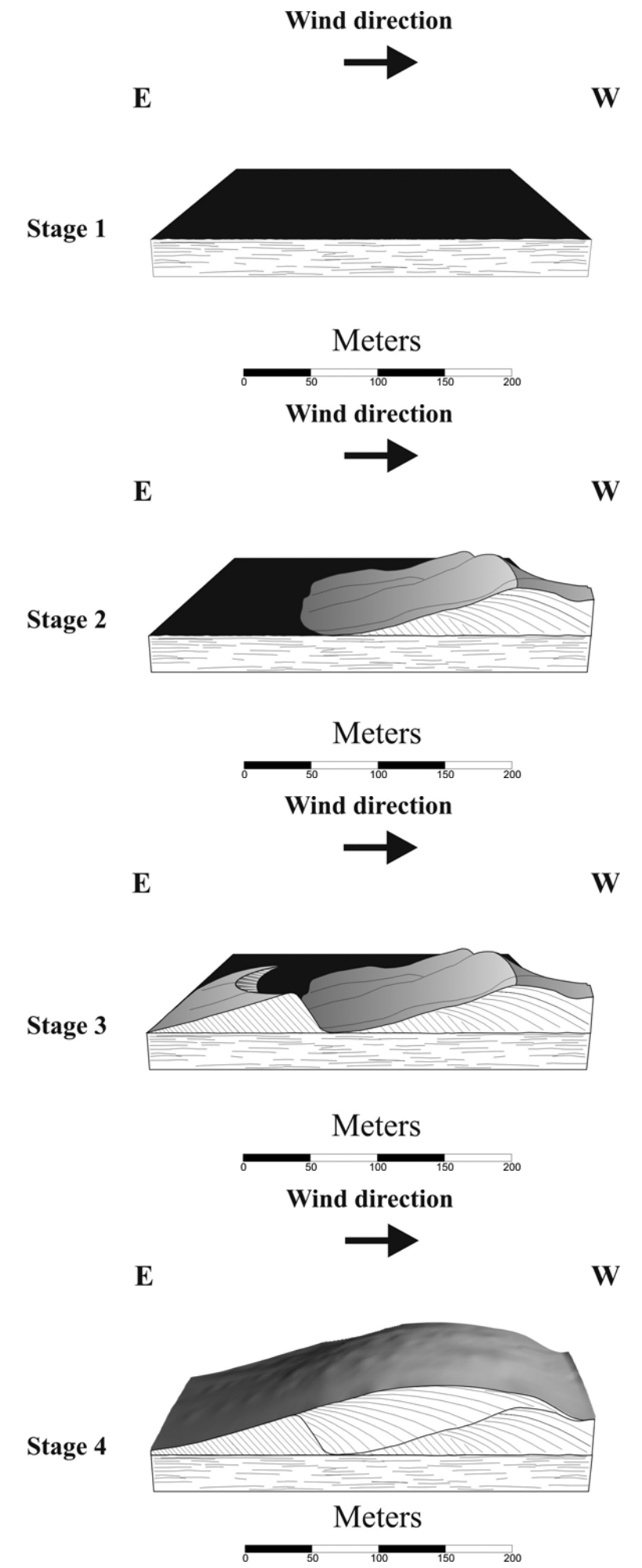

Figure 14 (a) - Schematic model for the four-stages depositional history of the area. Stage 1 - deposition of marine sediments during the last Holocene regression. (b) - Schematic model for the four-stages depositional history of the area. Stage 2 - first phase of aeolian deposition. (c) - Schematic model for the four-stages depositional history of the area. Stage 3 - development of a barchan dune and migration toward to the dune formed during Stage 2. (d) - Schematic model for the four-stages depositional history of the area. Stage 4 - morphology change of the dune from barchan to the present dome-shaped. 
The previous dominant winds were very similar to the present-day dominant wind, at least in direction. So, the rapid migration process of the dune toward urban areas is an entirely natural process.

\section{ACKNOWLEDGEMENTS}

Financial support to this study was given by MAMBMARÉ (Proc. CNPq no 468045/2000-7 - CNPq-CTPETRO), "Küstenentwicklung und Heutige Küstendynamik in Rio Grande do Norte - Ne-Brasilien" (GTZ/DFG), and PROBRAL CAPES/DAAD (98/072 and 150/02), an international cooperation between Brazil and Germany. The GPR equipment was acquired with PADCT 3/CNPq/FINEP financial support. J.G. Oliveira Jr. and W.F. Tabosa thank Brazilian Agency CAPES for the PhD fellowships in Germany, during the period September 2002-August 2003. W.E Medeiros and $\mathrm{H}$. Vital thank CNPq for the research fellowships (PQ). Adriano, Anne, Arthur, Ozian, and Valdocir helped in the field survey. Dr. Aderson F. do Nascimento kindly revised the English text.

\section{REFERENCES}

BRISTOW CS \& JOL HM. 2003. Ground Penetrating Radar in Sediments. Geological Society of London. Special Publication No. 211. 330 pp.

BRISTOW CS, PUGH J \& GOODALL T. 1996. Internal structure of aeolian dunes in Abu Dhabi determined using ground-penetrating radar. Sedimentology, 43: 995-1003.

BROOKFIELD ME. 1977. The origin of bounding surfaces in ancient aeolian sandstone. Sedimentology, 24: 303-332.

CALDAS LHO. 1996. Geologia costeira da região de São Bento do Norte e Caiçara do Norte, Litoral Norte Potiguar. Relatório de Graduação, Departamento de Geologia, UFRN, 83 pp.

CALDAS LHO. 2002. Late Quaternary coastal evolution of the northern Rio Grande do Norte coast, NE Brazil. Unpublished PhD Thesis, Institute of Geosciences, University Christian-Albrechts zu Kiel, 92 pp.

CALDAS LHO, OLIVEIRA Jr JG, MEDEIROS WE, STATTEGER K \& VITAL H. 2006. Geometry and evolution of Holocene transgressive and regressive barriers on the semi-arid coast of NE Brazil. Geo-Marine Letters, 26: 249-263.

COSTA NETO LX. 1997. Evolução geológica-geomorfológica recente da plataforma continental interna ao largo do Delta do Rio Açu, Macau-RN. Dissertação de Mestrado, Programa de Pós-Graduação em Geologia e Geofísica Marinha, UFF, 214 pp.

DAVIS JL \& ANNAN AP. 1989. Ground Penetrating Radar for high resolution mapping of soil and rock stratigraphy. Geophysical Prospecting, 37: $531-551$.
GAWTHORPE RL, COLLIER REL, ALEXANDER J, LEEDER MR \& BRIDGE JS. 1993. Ground Penetration Radar: application to sand body geometry and heterogeneity studies. Geological Society, London, Special Publication, 73: 421-432.

HARARI Z. 1996. Ground Penetrating Radar (GPR) for imaging stratigraphic features and groundwater in sand dunes. Journal of Applied Geophysics, 36: 43-52.

HAYT Jr WH. 1988. Engineering Electromagnetic. $5^{\text {th }}$ ed. London: McGraw Hill, 496 pp.

HUGGENBERGER P. 1993. Radar facies: recognition of facies patterns and heterogeneities within Pleistocene Rhine gravels, NE Switzerland. Geological Society, London, Special Publication, 75: 163-176.

HUSTEDT S. 2000. Aeolian morphodynamics in the region São Bento do Norte on the NE-coast of Brazil. Unpublished MSc. dissertation, University Christian-Albrechts zu Kiel, 102 pp.

IDEMA. 1999. Secretaria de Planejamento e Finanças. Instituto de Desenvolvimento Econômico e Meio Ambiente do Rio Grande do Norte - IDEMA. Informativo Municipal: São Bento do Norte, 5: 1-14.

JOHANSSON EM \& MAST JE. 1994. Three dimensional ground penetrating radar imaging using synthetic aperture time-domain focusing. SPIE, 2275: 205-214.

McKEE ED. 1966. Structures of dunes at White Sands National Monument, New Mexico (and a comparison with structures of dunes from other selected areas). Sedimentology, 7: 3-69.

McKEE ED. 1979. Sedimentary structures in dunes. In: McKEE ED (Ed.). A study of global sand seas. US Geol. Survey. Prof. Pap., 1052: 83-113.

MOUNTNEY N \& HOWELL J. 2000. Aeolian architecture, bedform climbing and preservation space in the Cretaceous Etjo Formation, NW Namibia. Sedimentology, 47: 825-849.

NEAL A. 2001. Ground-penetrating radar and its use in sedimentology: principles, problems and progress. Earth-Science Reviews, 66: 261330.

NEAL A \& ROBERTS CL. 2000. Applications of ground penetrating radar (GPR) to sedimentological, geomorphological studies in coastal environments. In: PYE K \& ALLEN JRL (Ed.). Coastal and Estuarine Environments: sedimentology, geomorphology and geoarchaeology. Geological Society London Special Publications, 175: 139-171.

NEAL A \& ROBERTS CL. 2001. Internal structure of a trough blowout, determined from migrated ground-penetrating radar profiles. Sedimentology, 48: 791-810.

OLHOEFT GR. 2000. Maximizing the information return from ground penetrating radar. Journal of Applied Geophysics, 43: 175-187.

OLIVEIRA Jr JG. 2001. Dois testes de imageamento com GPR em problemas de controle ambiental em regiões tropicais: migração de dunas 
e localização de dutos de óleo enterrados. Dissertação de Mestrado, PPGG, UFRN, 86 pp.

OLIVEIRA Jr JG, MEDEIROS WE, VITAL H, XAVIER NETO P \& STATTEGGER K. 2003. GPR imaging of the internal structure of a sand dune in Rio Grande do Norte State, Brazil. Journal of Coastal Research. Special Issue, 35: 271-278.

PEDERSEN K \& CLEMMENSEN LB. 2005. Unveiling past aeolian landscapes: a ground-penetrating radar survey of a Holocene coastal dunefield system, Thy, Denmark. Sedimentary Geology, 177: 57-86.

ROTH K, SCHULIN R, FLÜHER H \& ATTINGER W. 1990. Calibration of time domain reflectometry for water content measurement using a composite dielectric approach. Water Resources Research, 26: 2267-2273.

RUBIN DM \& HUNTER RE. 1985. Why deposits of longitudinal dunes are rarely recognized in the geologic record. Sedimentology, 32: 147-157.

SANDMEIER KJ. 2000. REFLEXW, Version 1.4, program for processing of seismic, acoustic or electromagnetic reflection and transmission data, version 1.4, Karlsruhe, Germany, 197 pp.

SCHENK CJ, GAUTIER DL, OLHOEFT GR \& LUCIUS, JE. 1993. Internal structure of an aeolian dune using ground penetrating radar. Spec. Publs. Int. Assoc. Sediment, 16: 61-69.

SILVA FG \& SCHERER CMS. 2000. Morphological characterization of ancient aeolian dunes using the ground-penetrating radar, Botucatu Formation, Southern Brazil. Revista Brasileira de Geociências, 30(3): 531-534.

STOLT R. 1978. Migration by Fourier transformation. Geophysics, 43: 23-48.

STOLTE C. 1994. E-MIGRATION: Image Enhancement for Subsurface Objects of Constant Curvature in Ground Probing Radar Reflection Data. Unpublished PhD. Thesis, University Christian-Albrechts zu Kiel, 87 pp.

SUTINEN R. 1992. Glacial deposits, their electrical properties and surveying by image interpretation and ground penetrating radar. Geological Survey Finland Bulletin, 359: 1-123.
TABOSA WF. 2000. Dinâmica costeira da região de São Bento do Norte e Caiçara do Norte-RN. Relatório de Graduação, Departamento de Geologia, UFRN, 76 pp.

TABOSA WF. 2002. Monitoramento Costeiro das Praias de São Bento do Norte e Caiçara do Norte - RN: Implicações para o Pólo Petrolífero de Guamaré. Dissertação de Mestrado, PPGG, UFRN, 112 pp.

TABOSA WF, LIMA ZMC, VITAL H \& GUEDES IMG. 2001. Monitoramento Costeiro das Praias de São Bento do Norte e Caiçara do Norte NE Brasil. Revista Pesquisas em Geociências, 28: 383-392.

TOPP GC, DAVIS JL \& ANNAN AP. 1980. Electromagnetic determination of soil water content: measurements in coaxial transmission lines. Water Resources Research, 16: 574-582.

TSOAR H. 1982. Internal structures and surfaces geometry of longitudinal (seif) dunes. J. Sed. Petrol., 52: 823-831.

VAN DAM RL. 2002. Internal structure and development of an aeolian river dune in the Netherlands, using 3-D interpretation of groundpenetrating radar data. Netherlands Journal of Geosciences, 81: 27-37.

VILAÇA JG, CUNHA EMS \& SILVEIRA IM. 1991. Levantamento Hidrogeológico do Município de Galinhos. Anais IV Congresso Nordestino de Ecologia. Recife: SNE, p. 56.

XAVIER NETO P \& MEDEIROS WE. 2006. A practical approach to correct attenuation effects in GPR data. Journal of Applied Geophysics, 59: 140-151.

XAVIER NETO P, OLIVEIRA Jr JG \& MEDEIROS WE. 2001. Processamento de dados de GPR como uma etapa imprescindível para obtenção de boas imagens sobre solos condutivos: Um exemplo associado à localização de dutos. $7^{\text {th }}$ International Congress of the Brazilian Geophysical Society. Salvador. CD-ROM.

YOUNG RA, DENG Z \& SUN J. 1995. Interactive processing of GPR data. The Leading Edge, April, 275-280.

\section{NOTES ABOUT THE AUTHORS}

Josibel Gomes de Oliveira Júnior received a BS (1998) in physics, a MS in geophysics (2001), and a PhD (2006) in geophysics, all degrees from Federal University of Rio Grande do Norte, Brazil. He studied in Germany, at the Christian-Albrechts Universität zu Kiel (2003), as part of his PhD research. He worked with seismic processing in CGG (2005-2006) and Brain Tecnologia (2006-2007). Presently he is working as geophysicist at Flamoil Serviços Ltda., in Natal/RN, Brazil. His areas of interest are processing and acquisition of seismic and GPR data. He is a member of SBGf.

Walter Eugênio de Medeiros received a BS (1981) in civil engineering from Federal University of Rio Grande do Norte, a MS (1987) in geophysics from Federal University of Bahia, and a PhD (1993) in geophysics from Federal University of Pará, Brazil. He is professor of Federal University of Rio Grande do Norte since 1983. His professional interests include inverse problems in geophysics, near-surface geophysics and exploration geophysics. He is a member of SBGf, SEG, and AAPG.

Werner Farkatt Tabosa received a BS (1999) in geology, a MS (2002) in environmental geology - coastal dynamics, and a PhD (2007) in environmental geology coastal dynamics, all degrees from Federal University of Rio Grande do Norte, Brazil. He studied in Germany, at the Christian-Albrechts Universität zu Kiel (2003), as part of his $\mathrm{PhD}$ research. Presently he is consultant. His areas of interest are marine geology and environmental geology. 
Helenice Vital received a BS (1986) in Geology from Federal University of Rio Grande do Norte, a MS (1988) in Marine and Environmental Geology from Federal University of Pará, and a PhD (1996) in Marine geology and geophysics from Christian-Albrechts Universität zu Kiel, Germany. She is professor of Federal University of Rio Grande do Norte since 1997 and CNPq researcher since 1999. Her professional interests include coastal and shelf evolution, coastal dynamics, sea-level changes and high resolution geophysics. She is a member of SBG, ABEQUA, SBGf, SEPM, JCR and AGU. 